\title{
Death and Aging in Shahnameh of Ferdowsi
}

\author{
Nooshin Mohajerin
}

\begin{abstract}
Pain and suffering are two feelings mixed with human being, and they are the signs of being amongst the many in this world, and have the world antiquity. Pain and suffering are two concepts in the Art and Literature which are seen among various classifications of all genres. One of the literary masterpieces with persistent and profound concepts demonstrating pain and suffering in human being is Shahnameh written by Ferdowsi Tusi. Shahnameh is an in-depth narrative epic comprising history and civilization of thousands years of Iran and Iranian. The first and the most important pain and suffering that could be seen in Shahnameh is death.. Ferdowsi beautifully complains about the world expressing that when he was young, he enjoyed a glorious position but later in aging, he complains about frailty. Finally, From Ferdowsi, the everlasting concern of mankind is death and aging. He complains that mankind is all enthusiastically trying to gather treasure and making a living, though the mighty pawn of death is in the realm of hunting, and human finally will have to abandon all properties to hug the cold soil. Ferdowsi also complains about aging accompanying weakness and hardship, so every mankind becoming old, will experience a especial pain and suffering.
\end{abstract}

Keywords - Death, aging, pain, suffer

\section{INTRODUCTION}

Pain and suffering are two feelings mixed with human being, and they are the signs of being amongst many in this world, and have the world antiquity. The moment of birth, starts with the first sign of pain, the pain of parturition, the pain of exile of the safe place of mother's womb, the suffering of separation from cradle of peace and presence in this world. Pain deals more with body and matter and suffer is the pain in soul.

The following meanings could be found in dictionary: (noun) 1200-1300 old French: peine, from Latin: poena, from Greek: poine payment, punishment, In your body the feeling you have when part of your body hurts. In your mind the feeling of unhappiness you have when you are sad, upset. Synonym: tender, stiff, sore, hurt.

Suffer: (verb) Pain/Illness: to experience physical or mental pain or illness. Bad situation: to be in a very bad situation that makes things very difficult for you. Bad experience, Became worse, (Longman Advanced American Dictionary)

Pain and suffering are two concepts in the Art and Literature which are seen among various classifications of all genres.

One of the literary masterpieces with persistent and profound concepts that demonstrated pain and suffering in human being, is Shahnameh written by Abu'l-Qasim Ferdowsi Tusi

Nooshin Mohajerin, Associate Professor, B.I.H.E and NUML, Tehran, Iran
(c.940-1020).Shahnameh comprises an in-depth life and history of thousands years of Iran and Iranian, Iran's civilization, evolution, from the creation of the first human, the emergence and evolution of human civilization, the heroic tales and the fights with evil, historical eras and formation of governments and overthrown of the last ancient Iranian government, in an exquisite way mixed with advice. Shahnameh all utterance about human eternal pains and sufferings that appears bitter to any noble and aware spirits at any time and place.(Ferdowsi, rationale and his poem,P.245) The theme of stories in Shahnameh is fortune and destiny and all oppressions related to sphere, cycle, and time.(Same)

The first and the most important pain and suffering which is seen in Shahnameh is death. It is a concept that have been perpetual concern of mankind and never compromised. Even those who found themselves ready to leave and settle with never died without any tear and sorrow. Accordingly, death is to have been supposed as the permanent fear and suffering in this world. The suffering of entrusting body into the grave, the suffering of farewell of beloveds, the suffering of losing all things attained, the yearning of not finding wished and wanted, the suffering of going to an unknown world or the suffering of to be finished. Although death has fear and a lot of suffering, the way it happens, also the death of people has the new suffering based on the passion in them, people who die simply in peace, compared to those who surrender to death with a lot of pain and losing some part of their body, both they themselves suffer more, also leave deeper sorrow in their dears' heart. Sometimes the pain accompanies him till he dies and the suffer which pawns in the spirit of beloved ones.

We are all hunt near death,

A head under crown and a head under helmet (Shahnameh, P.c.940-1020)

Shahnameh begins with Gaiumart kingdom. Gaiumart was the first mythic world king who began reign in the world beginning governance in the Zodiac month, Aries, the king that his name means the mortal being. He mourned in his only son-Siyamak.

Deaths of loved ones place in another class of suffering and sorrow; through this, the death of a child to have been assumed as the worst burning and the heart-rending suffering has always had the bloody tears. The death of child, is so suffering that the heroes of Shahnameh, each takes its bitter taste differently and Ferdowsi has showed it every time with a different calenture. But his message is the same everywhere: The death of child follows the greatest mourning and tragic sufferance.

Siamak-the son of Gaiumart- in support of his father, fight with baby demon and was killed. 
When Shah found his son's death, with grief turned black the world to him

Desended from the throne, and reeled,

Bashed his head, and nailed his hair and face

From both sides shed bloody tears and his heart bereaved,

His eyes full of tears as a spring cloud

The army shouted in crying,

They rowed in front of the king

They rowed in front of the king

Eyes as bloody cloud with a pale face (same, P.29)

The next mythic king is Fareidun. He had three sons named

Salm, Toor and Iraj. Ferdowsi introduced them as:

Two quarrelsome and one good natured, (Same-P.80)

Fareidun divided the world between his sons, gave Bizantine and the other eastern regions to Salm, Turkmenistan and China to Toor and tundra braves plain and Iran to Iraj.

When wise Fareidun got old, Salm, the oldest son deviated from the ritual of kingdom and sagacity and his being became full of greed. He was not satisfied with the division of lands by his father and objected why his father had given the habitable and treasured land to the junior son. Angrily with full of rancor he sent a herald to China to aware his brother. Toor was also disturbed by this.

Two brothers decided to send a messenger to their father and gave him a message that he had to take back Iran from Iraj for compensation and settle their oppression.

Fareidun shared it with Iraj and then his little son decided to go to his brothers without any army and extinguish the fire of rancor in their heart.

Two brothers killed Iraj of anger and sent his head to father. Fareidun that looked out his son, ordered to set up a party and decorating and wanted wine, instrument (Rood) and singers. When the king and his army prepared to welcome the king of Iran, they saw a courier galloping toward them. The courier carrying a gold coffin approached and opened it near Fareidun and brought out decapitated head of Iraj from silk.

Fareidun fell off from his horse,

The army, all, tore their clothes

Black his face went and blinds his eyes,

For he wished, could see otherwise

Another important aspect that was raised in Shahnameh is the effect of death as a tragedy. The killing of Sohrab by his father-Rostam- accompanies all sorrows of losing a child with the bigger sorrow; A father unconsciously killed his unseen, noble and naïve youth son with a dagger.

Sohrab looking for his father, wanted to dethrone Kai Kavoos and throne his father. Both Kai Kavoos and Afrasiab had the fear of the two heroes joint. When Rostam, in fighting, knelt down Sohrab and tore his side with a dagger, Sohrab warned him that his father will take revenge of his blood and showed the bead he had as a memory of his father tied on his arm.

When Rustam opened son's armor and saw the bead, He tore his clothes.

Kept tearing his hair and shedding bloody tears, putting the soil on his head with face full of tears (Same, P.338)

Rustam, mourning, said:"O'my arrogant hero youth! Never turning time will find like you. To whom has yet occurred such a thing, that one killed his young son in his old age. I deserve to cut my hands and descend to the ruins.

Whose father has ever done this,

I deserve now no bless

Whoever in the world has killed,

his brave wise and young son?

Professor John Hun Nin (from China) pinpoints four youth tragedies in Shahnameh in his issue: "Iraj, Sohrab, Esfandiaar and Siyawush. Three of them are princes. All not only are statuesque and powerful and gifted but also good-natured and well- disposed and have an iron will and faithful with great ambition. Their relatives have a hand in their death. The reason pushed them toward death, the reasons about the power of ambition and getting monarchy. (I do not die, for I am alive, P.101)

Although everyone is unique in his kind, and has his especial story, but their common message is rants of the prolific and worthy son, and there are many threnodies about sadness of losing child that is the most plaintive and finest threnodies in Persian language.

Sometimes death meets simply and calmly human that Ferdowsi has created uniquely innovative images of that:

Minuchihr's age turned to two hundred and sixty

He prepared for death

Astronomers went to him

They told some stories

They informed him about that bitter day

That the throne changed to gloomy

It comes the day to go to another place,

If you will find the better place by God (Shahnameh, P170)

When Minuchihr found himself close to death called and told

Zoroastrians his will, then called Nawzar and advised him:

This throne is just spell and ephemeral

Should not be relied forever (Same)

The moment of Minuchehr's passing has been depicted beautifully:

He closed his royal eyes

Faded and blew the cold breath

Passed away, that famed gifted king,

and just remained his speech in the world (Same, P.171)

Ferdowsi has a particular sight about death and asked:

If death is justice, so what injustice is?

What is too much cry and shout from justice

And he hopelessly expresses that our soul is not aware of this secret and this secret is open to nobody and the only hope is to rest in the better place.

The breath of death like horrible fire,

Has not any care/fear about young and old

To go to this way should not any delay

When you sit on the mortal horse, death will tighten the bridle

Know thou that is justice and not oppression 
So when is justice, then there should not be any cry (Same)

Ferdowsi believes that death do not discriminate young and old, and when the time comes, the age is not any important, and if our heart will be full of the light of faith, we should surrender to this final and express thralldom.

Ferdowsi has written about major human virtues in his poems: art as an acquired virtue, pearls of wiseness (inherent virtues), race as nobles, and finally wisdom that you have to achieve all four virtues. When one get all, being away of greed, sorrow and suffering.(Shahnameh,P.522)

But death is inevitable

There is not worse than shrewish fortune (Same, P.522)

He composes about inevitable death in Kai Khusraw's story:

We keep seeking, suffering and treasuring,

We fill our heart full of desire

Finally we inherit just soil,

Nobody can scape this. (Shahnameh, P.535)

in Kai Khusraw's story, the merciful, wise, well-known and just king as Ferdowsi brings" The world would not go without him and his crown"(Shahnameh,P.880) the view of death is changed, and turns as a desire for immortality. Kai Khusraw after fighting Afraisab, raised his hand to pray:

And said O'The superior!

The increaser of purity and greatness

You guid me to heaven

If I pass from this word (Shahnameh,P.979)

He follows heaven and has the pain of immortality. After giving his throne to Lohrasp, sit on the golden throne and speech to the great and heroes:

All will pass away and the world is transient,

Why have to be in pain, sorrow and suffer?

All have the fear of God,

You would not be safe on this dark soil

This day would soon come to us

World counts everyone's breath (Shahnameh, P.990)

Then he speaks about abandoning the world and desiring for immortality:

I wish I could leave the transient world,

And stay away of the sufferance (Same)

Kai Khosrow believes with passing away he will reach the eternality and better place. He knows death as a path from the ignoble world to the world of eternally.

He was going to highlands and reaching a spring,he calls to accompanies:

There comes the separation day for me,

If I could know Soroush

If my heart bears this prudence

I will tear off the darkened heart from my flesh (Same. 1000)

He says when sun rises, you cannot find me but in your dream, and makes a farewell. By this, he drowns down in the spring and disappears.

The world has such as faith and custom

And never picks the prosperous only

Choses either from the deprived ones,

Or from the throne
It would neither go contented with this, nor unhappy with that.

This is the custom of the world (Same, P.1002)

Here is what Miguel De Unamuno says about immortality:

"It is impossible for us, in effect, to conceive of ourselves as not existing, and no effort is capable of enabling consciousness to realize absolute unconsciousness, its own annihilation. Try, reader, to imagine to yourself, when you are wide awake, the condition of your soul when you are in a deep sleep; try to fill your consciousness with the representation of no-consciousness, and you will see the impossibility of it. The effort to comprehend it causes the most tormenting dizziness. We cannot conceive ourselves as not existing. (TRAGIC SENSE OF LIFE P.33)

Eternity, eternity! - that is the supreme desire! The thirst of eternity is what is called love among men, and whosoever loves another wishes to eternalize himself in him. Nothing is real that is not eternal. (Same, P.34)

To be, to be forever, to be without ending! Thirst of being, thirst of being more! hunger of God! Thirst of love eternalizing and eternal! To be forever! to be God!"(Same)

Our hunger for God, our thirst of immortality, of survival, will always stifle in us this pitiful enjoyment of the life that passes and abides not. It is the frenzied love of life, the love that would have life to be unending, that most often urges us to long for death. "If it is true that I am to die utterly,"(P.36)

In another image death is a hunter that all- from king to soldier- are its hunts.

We are all hunts of death.

A head under the crown and a head under helmet (Shahnameh, P.)

He compares death in the unique metaphor to a fierce lion lurking for human that has sharpened its paws in anger.

\section{CONCLUSION}

It seems Ferdowsi's soul always annoyed of the sorrow from death, and in fact he believes a part of human's faith.

O'you have raised the world,

Why you have me deprived in old age?

When I was young, you raised me with glory,

Why you humiliate me for nothing?

Ferdowsi complains about the world in a beautiful interpretation and expresses that when he was young, he enjoyed a glorious position but later in aging, he complains about frailty.

He explains the length of life in the present world with a unique comparison: "I found glory in my youth with you, but became despised in old age." He has likened the life to a flower turning yellow, and the body like cypress tree bended in old age. The black hair changed to white. He complains to the world and tells it that "you were in my youth as a kind and foster mother, but in old age you put me in pain that I kept bleeding at my heart, and says "I wish you had not fostered me or if you fostered, did not hurt me. He threatens it saying "when I go to the other world, I will complain of your oppression to God." 
Then he reproves about the changing in human appearance that is the natural evolution from youth to old age:

That cypress tree bended in halves,

Likewise dimmed his eyes that looked like a light

Also: If you live for a longtime,

For suffering of body we will need to go (Shahnameh, P.776)

All this means he becomes feeble when turning to old age.

Although pain and suffer are the commitments of the world, and everybody is afflicted, pain and suffer may vary in size and amount for different people, all mankind find a share of two kinds of pain and suffer tasting its bitterness. From Ferdowsi, the everlasting concern of mankind in the world is death and aging that he has inevitably surrendered. He complains that mankind is all - with enthusiasm -trying to gather treasure and making a living, though the mighty pawn of death is in the realm of hunting, and human finally will have to abandon all properties to hug the cold soil. Ferdowsi also complains about aging that accompanies weakness and hardship, pain and suffering, and every mankind becoming old, will experience an especial pain and suffering.

\section{ACKNOWLEDGMENT}

I would like to raise my thanks and gratitude to my teacher Mr. Najafzadeh who taught me writing into English and assisted me to edit the current paper

\section{REFERENCES}

[1] Ferdowsi, 1363. "Shah-nameh", Tehran-Iran: Amir Kabir Publisher

[2] Dehkhoda, Dictionary, CD.
[3] Qadam Ali Sarrami,"From the color of flower to the sting of thorn", The morphology of the Tales of Shahnameh,Tehran-Iran:Scientific\&Cultural Publication Compony, 1994.

[4] Riahi,Mohammad Amin "Ferdowsi, rationale and his poem" Tarhe now Publisher, 1996.

[5] Behfar, Mehri, 1380.The Shahnameh of Ferdowsi, detailed line by line interpretation, definition of difficult words, phrases and expressions and etymology of Persian words includes Arabic translation (Bundari) and the English translation (Atkinson), volume, Tehran-Iran: Hirmand Publisher.-

[6] Unamuno, Miguel de, "The Tragic sense of life", Internet Archive: Digital.

[7] Dr.Bastani Parizi,"The last part of Shahnameh is good",Atai publisher, Tehran-Iran, 1992.

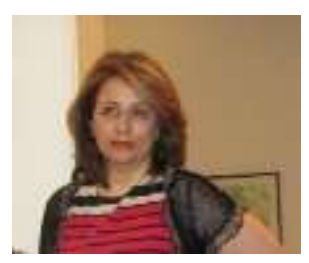

Nooshin Mohajerin author and researcher in Persian and English Literature, was born in Tehran- Iran in January. She graduated from natural science from high school. She has passed English Language for the B.A. program within 8 semesters at BIHE. Further, she majored Persian culture and literature in B.A. She started English Literature in Numl University of Pakistan as unaccomplished study for leaving the country. She had her first book published by A.D.E.L. in Germany; March2005. She had a collective work about Virginia Woolf, and also published some articles about Persian literature in different magazines. She has also been certified for submitting to some articles in International Conferences.

Ms. Mohajerin received two awards last year from university of Ontario, Canada (International Conference on Social Science, Literature, Economic and Education, Dubai-United Arab Emirates 2017), and QUEBEC (6th International Conference on Literature, Languages, Humanities and Social Sciences (L2HSS-2017-PARIS) 